Traffic Management Of Air Transportation On Noise Control In The Area Around Juanda Airport

\author{
Try Cahyo Adi Pamungkas, Sri Wiwoho Mudjanarko* \\ Department of Civil Engineering, Faculty of Engineering, University of Narotama \\ adisaplex@gmail.com, \\ *sri.wiwoho@narotama.ac.id
}

\begin{abstract}
This study aims to determine (1) the level of noise in the area around Juanda Airport, (2) the perception of the community in the area around Juanda Airport about the comfort of life with noise, and (3) public perception of the discourse on implementing environmental management in the area around Juanda airport. The locations in this study are on Jalan Raya Sedati Gede (A1) and Jalan H. Abdul Rahman Sedati Gede (A2). The data collection technique used is the measurement technique with the help of a sound level meter for noise data collection, while the public perception data collection uses a questionnaire technique. The analysis technique used for public perception data is to use descriptive statistical tests. The results showed that (1) the measurement results in residential areas were in accordance with the Noise Level Quality Standard Decree of the Minister of Environment, Kep 48 / MENLH / 11/1996. November 25, 1996, for the locations of Jalan Raya Sedati Gede (A1) $77.48 \mathrm{dBA}$, and Jalan H. Abdul Rahman Sedati Gede (A2) 67.43 Dba above the noise quality standard threshold for settlements of 55 dBA. (2) The majority of the people around Juanda Airport agree that flight activities at Juanda airport cause noise that cause discomfort, rest, and cause stress. (3) The community in the area around Juanda Airport agreed to the need for environmental management as an effort to control noise.
\end{abstract}

Keywords: Noise Level, Public Perception, Environmental Management

\title{
INTRODUCTION
}

Airplanes are a type of transportation that is increasingly needed. Tens or even hundreds of commercial airplanes fly from hundreds of airports around the world every day and create a serious problem, namely increased noise emission. Yet, noise does not kill humans, but it can make human life uncomfortable. If this happens continuously this can have an impact on the health of people around the airport.

The noise that occurs will certainly give discomfort to the people who live around the airport. Juanda Airport is one of the airports with high flight activity. This is due to the status of Juanda Airport as an international airport where all flight activities in eastern Indonesia are focused on Juanda Airport, both local and international flights.

The existence of a pandemic in 2020 is not an excuse for Juanda airport not to become congested. Indah Preastuty as PTS General Manager of Juanda Airport said that the number of passengers at Juanda Airport continued to increase. In the third quarter, the increase in passengers was very significant, namely, by 175 percent from the second quarter. The total number of passengers until the end of September at Juanda Airport reached 5.1 million passengers. This increase was due to the relaxation of flying rules for passengers during the pandemic period (Jawa Pos in October 2020). 
In more detail, the average aircraft movement in the third quarter was 146 movements per day or grew 92.1 percent compared to the second quarter with 76 movements per day. As for cargo, it was recorded as much as $179,430 \mathrm{~kg}$ per day in the third quarter, up 60.6 percent compared to the second quarter of $111,758 \mathrm{~kg}$ per day (Sidoardjo News in October 2020).

In connection with the problems mentioned above, namely the high level of noise, the immediate steps to be taken are environmental management. Environmental management measures that can be taken are installing barriers, installing sound absorbers in functional institutions, planting trees, planting shade plants in the buffer zone bordering community settlements (Purwanto, 2015).

From a regulatory perspective, there are already regulations regarding noise control issues. The regulation is the Ministry of Transportation No. KM. 4 of 2004. In the regulation, Article 3 Paragraph a, b, and c, states that the Noise Area around the airport consists of: (a) Noise area level 1 has a noise level value greater than or equal to 70 WECPNL up to smaller 75 WECPNL; (b) The noise level level 2 has a noise level value greater than or equal to 75 WECPNL up to less than 80 WECPNL; (c) the noise level level 3 has a noise value greater than or equal to 80 .

Referring to this regulation, it can be understood that the noise level generated by flight activities at Juanda is not allowed to be higher than the noise limit stipulated in the regulation. If it exceeds, then noise control efforts must be made inevitably.

Based on the results of the pre-research, some people in the research location still feel disturbed by the noise caused by flight activities at Juanda Airport. Even though several efforts to control noise have been made, the people who are active and live are still uncomfortable.

Referring to the results of the pre-research, the researcher considers that the noise level generated from flight activities at Juanda Airport has exceeded the noise limit as regulated in the regulation. This is the problem point why this research needs to be done, which is to prove directly about the noise level that occurs in the area around the airport.

The objectives of this study are (1) the level of noise in the area around Juanda Airport, (2) the perception of the community in the area around Juanda Airport about the comfort of life with noise, and (3) the public perception of the discourse on implementing environmental management in the area around Juanda airport.

\section{RESEARCH METHODS}

The locations in this study are on Jalan Raya Sedati Gede (A1) and Jalan H. Abdul Rahman Sedati Gede (A2). The data collection technique used is the measurement technique with the help of a sound level meter for noise data collection, while the public perception data collection uses a questionnaire technique. The analysis technique used for public perception data is to use descriptive statistical tests.

\section{RESEARCH RESULTS AND DISCUSSION}

\section{a. Noise Level in the Area Around Juanda Airport}

Based on the noise identification carried out in the area around Juanda International Airport in Surabaya, including Jalan Raya Sedati Gede (A1), and Jalan H. Abdul Rahman Sedati Gede (A2). So it can be seen the average noise level, momentary noise and respondents from the surrounding community and workers due to noise generated from aircraft engines.

\section{1) Momentary Noise Level}

The results of noise measurements after being calculated to find the instantaneous noise level for each location can be shown in the table. 
Table 1 Momentary Noise

\begin{tabular}{|c|c|c|c|c|c|}
\hline No & $\begin{array}{l}\text { Research } \\
\text { sites }\end{array}$ & Date & Time & $\begin{array}{c}\text { Leq } \\
\text { (dBA) }\end{array}$ & $\begin{array}{l}\text { Momentary } \\
\text { Noise Level } \\
\text { (dBA) }\end{array}$ \\
\hline \multirow{6}{*}{1.} & \multirow{6}{*}{$\begin{array}{c}\text { Jalan Raya } \\
\text { Sedati } \\
\text { Gede }\end{array}$} & \multirow{3}{*}{$\begin{array}{r}\text { January } \\
16,2021\end{array}$} & Pagi & 79,03 & 89,03 \\
\hline & & & Siang & 76,1 & 86,1 \\
\hline & & & Sore & 77,47 & 87,47 \\
\hline & & \multirow{3}{*}{$\begin{array}{c}\text { January } 17, \\
2021\end{array}$} & Pagi & 78,37 & 88,37 \\
\hline & & & Siang & 79,87 & 89,87 \\
\hline & & & Sore & 74,07 & 84,07 \\
\hline \multirow{6}{*}{2.} & \multirow{6}{*}{$\begin{array}{c}\text { Jalan H. } \\
\text { Abd. } \\
\text { Rahman } \\
\text { Sedati } \\
\text { Gede }\end{array}$} & \multirow{3}{*}{$\begin{array}{r}\text { January } \\
16,2021\end{array}$} & Pagi & 70,97 & 80,97 \\
\hline & & & Siang & 64,23 & 74,23 \\
\hline & & & Sore & 72 & 82 \\
\hline & & \multirow{3}{*}{$\begin{array}{c}\text { January } 17 \\
2021\end{array}$} & Pagi & 68,53 & 78,53 \\
\hline & & & Siang & 66,4 & 76,4 \\
\hline & & & Sore & 62,47 & 72,47 \\
\hline
\end{tabular}

The table 1 above shows that the highest result of instantaneous noise is $89.87 \mathrm{dBA}$, and the lowest value of instantaneous noise is $72.47 \mathrm{dBA}$. The fluctuating noise level is influenced by the weather conditions during the study, the temperature during the study, the air pressure, the wind speed, and the density of the flight schedule. If the weather is bad, the flight density decreases, so that airport activity is relatively quiet.

\section{2) Average Noise Level}

From the results of the noise level measurement, the average noise level or Leq data is obtained. With 6 measurements at each point of the measurement location, as in the table 2:

Table 2 Average Noise Calculation Results

\begin{tabular}{|c|l|c|c|c|c|}
\hline \multicolumn{5}{|c|}{ Noise Measurement Results } \\
\hline No & \multicolumn{1}{|c|}{ Location } & Lmax & Lmin & Leq & $\begin{array}{c}\text { Quality } \\
\text { standards }\end{array}$ \\
\hline 1. & Jalan Raya Sedati Gede & 94,88 & 59,43 & 77,48 & 55 \\
\hline 2. & $\begin{array}{l}\text { Jalan H. Abd. Rahman Sedati } \\
\text { Gede }\end{array}$ & 91,92 & 44,04 & 67,43 & 55 \\
\hline
\end{tabular}

Information:

\begin{tabular}{|c|c|}
\hline Lmax & : Maximum Noise Level when Measuring. \\
\hline Lmin & Minimal Noise Level when Measuring. \\
\hline Leq & $\begin{array}{l}\text { Variable noise level value which is equivalent to the noise level of a } \\
\text { constant noise for } 10 \text { minutes }\end{array}$ \\
\hline$\left.{ }^{* *}\right)$ & $\begin{array}{l}\text { : Noise Level Quality Standards Decree of the Minister of Manpower No. } \\
\text { Kep.51 / MEN / 1999. April 16, } 1999 .\end{array}$ \\
\hline$\left.{ }^{*}\right)$ & $\begin{array}{l}\text { Noise Level Quality Standards Decree of the State Minister for the } \\
\text { Environment Kep 48/MENLH/11/1996. November 25, } 1996 .\end{array}$ \\
\hline
\end{tabular}

Based on the results of measurements in residential areas in accordance with the provisions of the Noise Level Quality Standard Decree of the State Minister for the 
Environment Kep 48 / MENLH / 11/1996 November 25, 1996, for the locations of Jalan Raya Sedati Gede (A1) 77.48 dBA, and Jalan H. Abd Rahman Sedati Gede (A2) 67.43 $\mathrm{dBA}$, where the noise level exceeds the quality standard provisions as regulated in the Ministerial Decree concerned.

The measurement results obtained in the field are strongly influenced by weather, wind, and natural and technical conditions that occurred during the research period. The better the weather and conditions that occur, the more supportive the research results will be obtained because the continuity of the research runs smoothly.

b. Community Perceptions Around Juanda Airport on Noise Levels Caused by Aviation Activities and Public Perceptions of Environmental Management Measures as Efforts to Control Noise

In determining the number of class intervals in calculating the following formula is used:

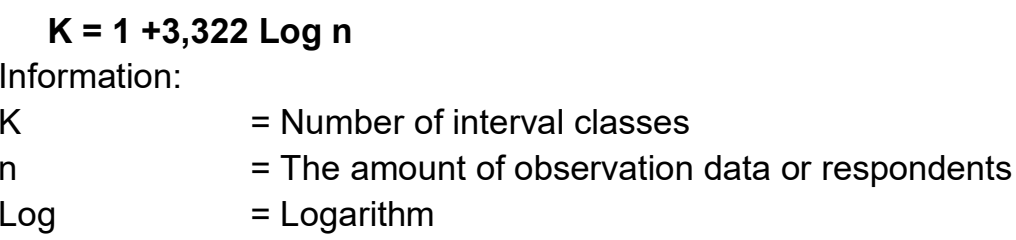

From the calculation it is known that $\mathrm{n}=20$ so that the number of classes $1+3.322 \log 20=$ 5.321 is rounded to 5 .

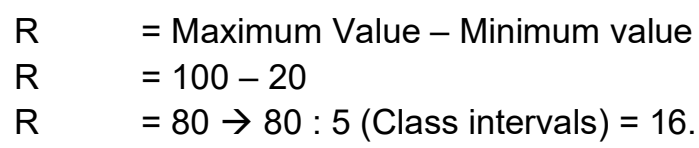

The purpose of using frequency tables is to classify the assessment criteria for each variable in the question item.

Table 3 Research Variable, Questionnaire Frequency Table

\begin{tabular}{|c|c|c|}
\hline No & Frequency & Information \\
\hline 1 & $20-36$ & Strongly Disagree \\
\hline 2 & $37-52$ & Disagree \\
\hline 3 & $53-68$ & Neutral \\
\hline 4 & $69-84$ & Agree \\
\hline 5 & $85-100$ & Strongly agree \\
\hline
\end{tabular}

1) Public Perception of Noise Levels Caused by Aviation Activities

Table 4 Public Perception of Noise

\begin{tabular}{|c|l|c|c|}
\hline No & \multicolumn{1}{|c|}{ Statement } & Count & Information \\
\hline 1. & Flight activity at Juanda Airport is very dense & 73 & Agree \\
\hline 2. & $\begin{array}{l}\text { The high flight activity at Juanda airport results } \\
\text { in high noise levels. }\end{array}$ & 73 & Agree \\
\hline 3. & $\begin{array}{l}\text { High noise really disturbs your comfort while } \\
\text { on the move. }\end{array}$ & 67 & Neutral \\
\hline 4. & $\begin{array}{l}\text { High noise really disturbs your comfort while } \\
\text { resting. }\end{array}$ & 76 & Agree \\
\hline 5. & High noise causes stress for you & 72 & Agree \\
\hline
\end{tabular}


The table 4 shows that the result of scores for answers / responses of respondents to the statements "Flight activity at Juanda Airport is very dense", and "High flight activity at Juanda airport results in high noise levels" is the same, which is 73 . This shows that the respondents agreed that flight activities at Juanda Airport were very dense and resulted in high levels of noise.

Moreover, the number of scores for answers / responses of respondents to the statement "High noise really disturbs your comfort while on the move" is 67 . This shows that the respondents stated neutral that high noise really disturbs your comfort while on the move. Then, for the statement "High noise really disturbs your comfort while resting", the responses show value of 76 . This firmly shows that the respondents agreed that high noise really disturbs their comfort file resting. Lastly, the table 4 shows that the number of scores of responses / responses of respondents to the statement "High noise causes stress for you", is 72 . This shows that the respondents agreed that high noise causes stress.

Based on the results of this study, it can be concluded that the people who both live and have activities in the area around Juanda Airport, the majority agree that flight activity at Juanda Airport is very high and the result of these flight activities causes noise which causes discomfort in activities, resting, and tends to lead to stress.

2) Public Perception Around Juanda Airport on Environmental Management Measures as Efforts to Control Noise

Table 5 Community Perceptions of Environmental Management Measures

\begin{tabular}{|c|l|c|c|}
\hline No & \multicolumn{1}{|c|}{ Statement } & Count & Information \\
\hline 1. & $\begin{array}{l}\text { It is necessary to plant trees around the road body } \\
\text { where you do your activities / live. }\end{array}$ & 74 & Agree \\
\hline 2. & $\begin{array}{l}\text { It is necessary to plant shady plants in the buffer } \\
\text { zone bordering the settlement. }\end{array}$ & 72 & Agree \\
\hline 3. & $\begin{array}{l}\text { It is necessary to install a barrier to reduce noise } \\
\text { and gas emissions from the aircraft. }\end{array}$ & 72 & Agree \\
\hline 4. & $\begin{array}{l}\text { It is necessary to install sound insulation / silencers } \\
\text { in office buildings, schools, and other functional } \\
\text { institutions in your location of activities / living. }\end{array}$ & 76 & Agree \\
\hline
\end{tabular}

The table 5 shows that the number of scores of respondents' answers / responses to the statement "It is necessary to plant trees around the road body where you do your activities / live", is 74 . This shows that the respondents agreed that it is necessary to plant trees around the body. road at the location for activities / living. Moreover, the number of scores of answers / responses of respondents to the statement "It is necessary to plant shady plants in a buffer zone that borders the settlement", is 72 . This shows that the respondents agreed that it is necessary to plant shady plants in the buffer zone bordering settlement.

The research finds that the number of scores of respondents' answers / responses to the statement "It is necessary to install a barrier to reduce noise and gas emissions from the aircraft", is 72 . This shows that the respondents agree that it is necessary to install a barrier to reduce noise and exhaust gas from the plane. And finally, the number of scores of answers / responses of respondents to the statement "It is necessary to install sound insulation / silencers in office buildings, schools, and other functional institutions in the location where you live / live", is 76. This shows that the 
respondents stated that Agree that it is necessary to install sound insulation / silencers in office buildings, schools, and other functional institutions in locations where people have activities / live.

Based on the results of this study, it can be concluded that the majority of people who live and do activities in the area around Juanda Airport agree to the need for environmental management as an effort to control noise.

\section{CONCLUSION}

Based on the research results above, it can be concluded that the following are:

a. The results of measurements in residential areas are in accordance with the provisions of the Noise Level Quality Standard Decree of the State Minister for the Environment Kep 48 / MENLH / 11/1996. November 25, 1996, for the locations of Jalan Raya Sedati Gede (A1) $77.48 \mathrm{dBA}$, and Jalan H. Abdul Rahman Sedati Gede (A2) 67.43 Dba above the noise quality standard threshold for settlements of $55 \mathrm{dBA}$.

b. The majority of people who live and do activities in the area around Juanda Airport agree that flight activity at Juanda Airport is very high and the result of this flight activity creates noise which causes discomfort in activities, resting, and tends to cause stress.

c. People who both live and do activities in the area around Juanda Airport have agreed to the need for environmental management as an effort to control noise.

\section{REFERENCES}

Cahyadi, H. (2018). Noise Due to Flight Activities at the Airport. Word Journal, 8 (2), 20.

Daniel Sondakh (2014). Analysis of Noise Pollution on Airport Environment (Case study of International Airport of Sam Ratulangi Manado, Indonesia) Keywords: Airport Environment Noise Pollution, Level of Noise Equivalent, Noise Level Treshold, Noise restraint at the source; Noise restraint on the transmission path; and Noise restraint on humans. International Journal of Engineering and Management Sciences.

Ismiyati, D. P. (2014). Environmental Management of Transportation as the Impact of Uncontrolled Urban Development (Semarang City Case Study). Journal of the Department of Civil Engineering, Faculty of Engineering, Diponegoro University.

JatimTribunNew. (2018). Retrievedfrom https://jatim.tribunnews.com/2019/01/10/selama-tahun2018-bandara-juanda-layani-209-juta-penumpang-jumlah-naik-41-persen-dibanding2017.

Jawa Pos. (2020). Jumlah Penumpang di Bandara Juanada Meningkat hingga 16 Persen. https://www.jawapos.com/surabaya/28/10/2020/jumlah-penumpang-di-bandara-juandameningkat-hingga-16-persen

General, D., \& Air, P. (2014). Source: Directorate General of Civil Aviation (2014). 1-7.

Decree of the State Minister for the Environment Number Kep48 / MENLH / 11/1996 concerning Noise Level Standards.

Klobor, Ignasius Maksimilian. (2019). Noise Level Analysis at El Tari Kupang International Airport, East Nusa Tenggara Province.

liputan6.com. (2019). Retrievedfrom https://surabaya.liputan6.com/read/4037840/kapasitasbandara-juanda-bakal-naik-jadi-136-juta-penumpang, diakses pada Oktober 2020. 


\section{THE SPIRIT OF SOCIETY JOURNAL}

International Journal of Society Development and Engagement

ISSN : 2594-4777 (Online) - ISSN : 2597-4742 (Print)

This work is licensed under a Creative Commons Attribution - ShareAlike 4.0 International License.

Miftahul Anam. (2016). Analysis of the level of noise and comfort of the community in the area around Lombok International Airport. 14-15.

Muliasari, Ataline. (2010). Determination of the Noise Area of Yogyakarta Adi Sucipto Airport.

Ninda, R., \& Rudy, L. (2012). The Influence of Noise from the Activities of Juanda International Airport, Surabaya. Envirotek: Scientific Journal of Environmental Engineering, 4 (1), 19-26.

Permenkes Number 718 / Menkes / Per / XI / 1987 concerning Understanding and Categories of Noise.

Purwanto. (2015). Environmental Management of Transportation as the Impact of Uncontrolled Urban Development (Semarang City Case Study). Civil Engineering Communication Media, 20 (1), 93-101. https://doi.org/10.14710/mkts.v20i1.9250

Rachman, I., \& Pristianto, H. (2018). Analysis of Air Traffic Noise Around DEO Airport, Sorong City. July. https://doi.org/10.31227/osf.io/yd8km

Ririn Warnidasari. (2017). Airport planning. 1-26.

Suma'mur. (2014). Company Hygiene and Work Safety. Jakarta: CV Sagung Seto.

Sidoardjo News. (2020). Still in the Middle of a Pandemic, the Number of Aircraft Passengers at Juanda Airport Increases. https://sidoarjonews.id/masih-di-tengah-pandemi-jumpenumpang-pesawat-di-bandara-juanda-men Increase/, accessed on November 2020.

Syaiful and Mudjanarko. (2019). Noise of Motor Vehicles at from of Baiturrahman Great Mosque Semarang City. International Journal of Society Development and Engagement.

Ugm, M. (2015). Air Traffic Management. 1-15.

(C) 2021 by the authors. Submitted for possible open access publication under the terms and conditions of the Creative Commons Attribution (CC BY SA) Creative Commons Atribusi-BerbagiSerupa 4.0 Internasional. 